\title{
STOK KARBON DI ATAS PERMUKAAN TANAH PADA HUTAN MANGROVE SUNGAI AWAN KIRI KABUPATEN KETAPANG
}

\author{
(Above Ground Carbon Stock in Sungai Awan Kiri Mangrove Forest Ketapang Regency) \\ Kusmawati, Gusti Hardiansyah, Ganjar Oki widhanarto \\ Fakultas Kehutanan Universitas Tanjungpura. Jalan Daya Nasional Pontianak 78124 \\ Email: Kusma898@gmail.com
}

\begin{abstract}
Mangrove forests, often referred to as mangrove forests, brackish forests or tidal forests, is a transitional ecosystem between land and sea which are tropical or sub-tropical areas along the sheltered coast and river mouth. Mangrove forest is a coastal plant community dominated by several species of mangrove trees that are able to grow and develop during the tides in accordance with their tolerance to salinity, duration of inundation, substrate and beach morphology. Awan Kiri Mangrove Forest has a total area of 114 hectares including the area of Other Management Areas (APL) then seen from the density of the Mangrove Forest only has 92 hectares. This study uses a non-destructive survey method. Vegetation carbon stock calculation is carried out using vegetation biomass calculation approach. Vegetation biomass calculation based on the calculation of allometric equations. Calculation the value of stored carbon using the formula according to (SNI 7724:2011) the value of parent carbon content, amounting to 0,47. Bassed on the research that has been done, it is found that there are 185 individuals, Rhizophora spp., Bruguiera gymnorhiza, Rhizpphora apiculata, Xylocarpus gerantum and Excoecaria agallocha. The biomassa content can be known in the 3 pathways to store 242,16 tons biomassa and the total biomassa content in 1210,8 tons/ha with an everage of 403,6 tons/ha. The carbon content is 569,06 tons/ha so that it gets an average total of 186,68 tons C/ha.
\end{abstract}

Keywords: Carbon Stock, Ketapang Regency, Sungai Awan Kiri in Mangrove Forests.

\section{PENDAHULUAN}

Hutan mangrove merupakan nama kolektif untuk berbagai vegetasi pohon yang menempati pantai berlumpur di dalam wilayah pasang surut, dari pasang tertinggi sampai tinggai air rendah. Wilayah hutan mangrove mempunyai ekosistem yang unik, dengan fungsi yang bermacam macam. Dilihat dari segi ekosistem perairan, hutan mangrove mempunyai arti yang penting karena memiliki fungsi ekologis. Hal ini mengingat hutan mangrove juga merupakan tempat mencari makan (feeding ground), daerah asuban (nursery ground), dan juga merupakan tempat pemijahan (spawing ground) dari berbagai jenis biota laut (Tiku, 2007).

Pemanasan global adalah salah satu isu lingkungan penting yang saat ini menjadi perhatian berbagai pihak. Akibat pemanasan global antara lain meningkatan temperatur rata-rata atmosfer laut dan darat bumi yang disebabkan oleh kegiatan industri dan semakin berkurangnya penutupan lahan khususnya hutan akibat laju degradas (Chanan, 2012). Penyebab terjadinya pemanasan global adalah Gas Rumah Kaca (GRK) terutama sisa pembakaran yang mengudara yaitu $\mathrm{CO}_{2}$. Peningkatan $\mathrm{CO}_{2}$ di atmosfer, disebabkan oleh 
berkurangnya hutan sebagai terjadi efek rumah kaca (Manuri et al. 2011).

Pada tahun 2015 menurut FAO (2007) luasan hutan mangrove di Indonesia tersisa 3,06 juta hektar. Tahun 2007 Kementerian Kehutanan merilis data terbaru luasannya menjadi 7,76 juta hektar atau berkurang 10\%, sementara itu Spalding et al. (2010) menyebutkan luasan hutan mangrove di Indonesia tersisa 3.189.159 hektar. NASA tahun 2010 mengeluarkan data selama rentang 1980-2000 mangrove di Indonesia telah berkurang 35\% dari luasan 4,2 juta hektar menjadi 3,73 juta hektar (Bakar, 2012).

Hutan mangrove sering juga disebut sebagai hutan bakau, hutan payau atau hutan pasang surut, merupakan suatu ekosistem peralihan antara darat dan laut terdapat didaerah tropik atau sub tropik disepanjang pantai yang terlindung dan dimuara sungai. Hutan mangrove merupakan komunitas tumbuhan pantai yang didominasi oleh beberapa jenis pohon mangrove yang mampu tumbuh dan berkembang pada saat pasang surut sesuai dengan toleransinya terhadap silintas, lama penggenangan, substrat dan marfologi pantainya (Anonim, 2002).

Tumbuhan memerlukan sinar matahari, gas asam arang $\left(\mathrm{CO}_{2}\right)$ yang diserap oleh udara sera dan hara yang diserap dari dalam tanah untuk kelangsungan hidupnya. Melalui fotosintesis, $\mathrm{CO}_{2}$ di udara diserap oleh tumbuhan dan diubah menjadi karbonhidrat, kemudian disebarkan keseluruh tubuh tanaman dan akhirnya ditimbun dalam tubuh tanaman. Proses penimbunan $\mathrm{C}$ dalam tubuh tanaman dinamakan proeses sekuestrasi ( $C$ sequestration), dengan demikian mengukur jumlah $\mathrm{C}$ yang tersimpan dalam tubuh tanaman hidup (biomassa) pada suatu lahan dapat menggambarkan banyaknya $\mathrm{CO}_{2}$ di atmosfer yang terserap tanaman (Hairiah dan Rahayu, 2007).

Nilai karbon yang terkandung pada vegetasi mangrove merupakan potensi dari mangrove dalam menyimpan karbon (stok karbon) dalam bentuk biomassa. Perhitungan stok karbon dalam suatu ekosistem mangrove dapat digunakan untuk mengetahui kemampuan ekosistem mangrove tersebut dalam menyerap gas-gas yang menyebabkan pemanasan global.Adanya upaya yang dilakukan untuk mengendalikan konsentrasi karbon di atmosfer, maka dapat digunakan untuk mengurangi jumlah $\mathrm{CO}_{2}$ di atmosfer (Chanan, 2012).

Sejarah perkembangan perusahaan HPH di Kalimanta barat terdapat sebanyak 97 buah perusahaan HPH dan 9 buah diantaranya di terbit izin oleh Bupati. Terbitnya izin HPH murni dari Bupati merupakan refleksi dan reformasi kebijakan sektor kehutanan melalui UU No.22 dan 41 Tahun 1999 serta PP No.25 Tahun 2000 dimana Mentri melimpahkan sebagian kewenangannya kepada Bupati sehingga kewenangan tersebut, Bupati menerbitkan SK HPH murni untuk pengusaha kecil dan lokal serta SK HPH 100 ha untuk masyarakat lokal dan koperasi serba usaha (KSU) 
disekitar kawasan hutan (Tim peneliti CIFOR Pontianak, 2002).

Gambaran sejarah tentang hutan di Kalimantan Barat, salah satunya hutan mangrove Sungai Awan Kabupaten Ketapang. Hutan mangrove Sungai Awan terbagi menjadi dua bagian yaitu Sungai Awan Kanan dan Sungai Awan Kiri. Hutan mangrove Sungai Awan Kabupaten Ketapang memiliki hutan mangrove yang berpotensi menyerap gas $\left(\mathrm{CO}_{2}\right)$ di atmosfer sebagai mengurangi efek rumah kaca. Berbagai uapaya yang dilakukan oleh kelompok masyarakat dan pemerintah untuk mempertahankan keberadaan hutan mangrove tersebut terutama rehabilitas hutan yang telah rusak. Pada saat ini besarnya simpanan karbon (stok karbon) pada hutan mangrove Sungai Awan masih belum diketahui. Maka sehubungan dengan permasalahan tersebut perlu dilakukan penelitian mengenai stok karbon di atas permukaan tanah pada hutan mangrove Sungai Awan Kiri Kabupaten Ketapang. Sebagai pemahaman bagi manfaat ekologi mangrove sebagai penyimpan karbon sehiggga usaha konservasi mangrove dalam rangka mengurangi pemanasan global dapat ditingkatkan.

Tujuan penelitian ini adalah mengetahui stok karbon di atas permukaan tanah pada hutan mangrove. Manfaat penelitian ini yaitu memberikan informasi tentang potensi penyerapan $\mathrm{CO}_{2}$ oleh hutan mangrove untuk mengatasi perubahan iklim.

\section{METODE PENELITIAN}

Penelitian ini dilakukan pada hutan mangrove Sungai Awan Kiri, dengan waktu penelitian \pm 4 minggu di lapangan terhitung dari tanggal 15 juni 2019. Kegiatan pelaksanaan penelitian ini menggunakan metode survei dengan pengambilan sampel secara nondestructif. Data yang diambil adalah diameter pohon dan jenis mangrove, menggunakan petak ukur $10 \mathrm{~m}$ x $10 \mathrm{~m}$, semua jenis pohon berdiameter $\geq 5 \mathrm{~cm}$ diukur diameter nya menggunakan meteran. Petak ukur dibuat kanan kiri selang seling, dengan rincian 10 petak di kanan dan 10 petak di kiri, lebar jalur petak ukur 20 meter dengan panjang 200 meter. Total dibuat sebanyak tiga jalur dengan luas setiap jalur 0,2 hektar. Sementara itu, total luas hutan mangrove Sungai Awan Kiri adalah 92 hektar. Analisis data menggunakan persamaan allometrik dengan rumus sebagai berikut:

Pengukuran Biomassa Pohon (Tree Biomass Measurement)

Data yang diambil pohon yang berupa diameter dan jenis mangrove, menggunakan petak ukur sebagai berikut: 


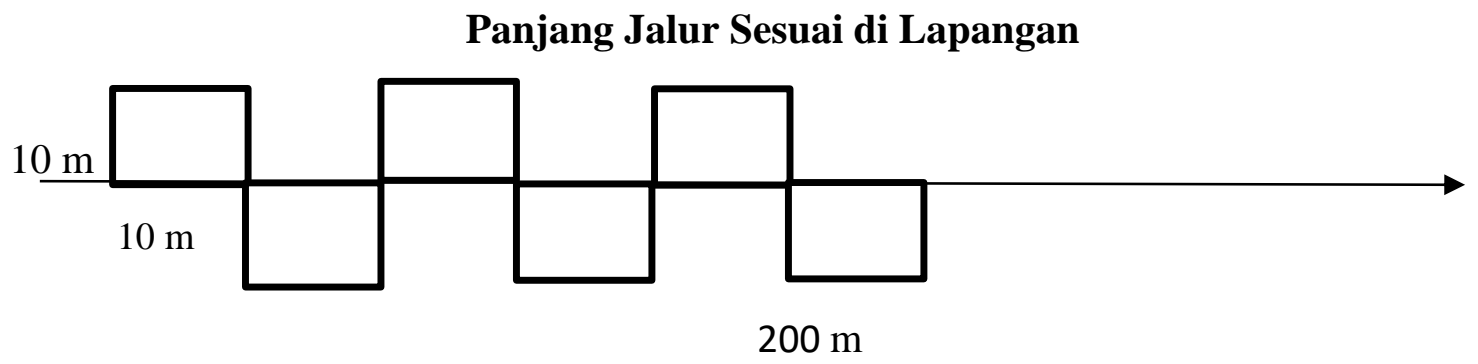

Gambar 1. Bentuk Plot Pengukuran Karbon Hutan (Plot Form for forest carbon measurement)

Keterangan :

Semua pohon bakau berdiameter $\geq 5 \mathrm{~cm}$ diukur dalam plot $10 \mathrm{~m}$ x $10 \mathrm{~m}$, plot dibuat kanan kiri selang seling. Ada 10 plot dikanan dan 10 plot dikiri, lebar jalur plot 20 meter dengan panjang 200 meter.

Data yang di peroleh di lapangan berupa jenis pohon dan keliling pohon maka untuk mendapatkan diameter pohon menggunakan rumus sebagai berikut:

\section{$\mathrm{DBH}(\mathrm{cm})=$ Keliling $/ \pi$}

Setelah didapatkan diameter $(\geq 5$ $\mathrm{cm}$ ) maka dilakukan perhitungan biomassa dan kandungan karbon yang dilakukan pada setiap jenis pohon

Tabel 1. Rumus Persamaan Allometrik Biomassa (Biomass Allometric Equation Formula)

\begin{tabular}{|c|c|c|c|}
\hline Jenis pohon & Persamaan Allometrik & $\mathbf{P}$ & Sumber \\
\hline Brugeria gymnorhiza & Wtop $=0.186 \mathrm{DBH}^{2.31}$ & - & $\begin{array}{l}\text { Clought and Scott (1989) dalam } \\
\text { komiyama et al,. (2007). }\end{array}$ \\
\hline R. apiculata & Wtop $=0.235 \mathrm{DBH}^{2.42}$ & - & $\begin{array}{l}\text { Ong et al. (2004) dalam } \\
\text { komiyama } \text { et al.. (2007). }\end{array}$ \\
\hline Xylocarpus grantum & Wtop $=0.0823 \mathrm{DBH}^{2.59}$ & - & Clought and Scott (1989). \\
\hline Rhizophora spp & Wtop $=0.235 \mathrm{DBH}^{2.42}$ & - & $\begin{array}{l}\text { Ong et al. (2004) dalam kepala } \\
\text { Badan Infomasi Geospasial } \\
(2014) \text {. }\end{array}$ \\
\hline Excoecaria agallocha & $\begin{array}{c}\text { Log Biomass }=1.0996 \log \\
\mathrm{DBH}^{\wedge 2}-0.8572\end{array}$ & - & $\begin{array}{l}\text { Hossain M, MRH Saha S and } \\
\text { Wetlands Ecol Manage (2015) }\end{array}$ \\
\hline
\end{tabular}

Dimana :

Wtop = Biomassa atas permukaan tanah

$P \quad=$ Berat jenis pohon

$\mathrm{DBH}=$ Diameter $(\geq 5 \mathrm{~cm})$ mangrove yang ditemui dalam tiga jalur penelitian. Perhitungan Stok karbon vegetasi dilakukan pendekatan perhitungan biomassa vegetasi. Perhitungan biomassa vegetasi di etimasi berdasarkan perhitungan persamaan allometrik. Rumus persamaan allometrik biomassa untuk jenis mangrove yang ditemukan adalah sebagai berikut: 


\section{Perhitungan Nilai Karbon Tersimpan (Calculation of stored carbon value)}

Menghitung nilai karbon tersimpan dengan menggunakan rumus menurut (SNI 7724:2011) sebagai berikut:

\section{$\mathrm{Cb}=\mathrm{B} \mathrm{X} \% \mathrm{C}$ organik}

Keterangan :

Cb : Kandungan karbon dari biomassa $(\mathrm{kg})$

B : Total biomassa pohon $(\mathrm{kg})$

\%C organik : Nilai persen karbon kandungan karbon, sebesar 0,47 atau menggunakan nilai persen karbon yang di peroleh dari hasil pengukuran di laboratorium.

\section{HASIL DAN PEMBAHASAN}

Berdasarkan pengambilan data dari pengukuran dan pengamatan secara langsung di lapangan, diperoleh hasil ekosistem hutan mangrove, kerapatan tegakan, kandungan siomassa dan stok karbon tersimpan pada Hutan Mngrove Sungai Awan Kiri Kabupaten Ketapang. Ekosistem Hutan Mangrove (Mangrove Forest Ecosystem)

Mangrove Sungai Awan Kiri merupakan mangrove yang tumbuh secara alami di sekitaran Sungai Etok, mangrove tumbuh secara alami bertujuan untuk menahan laju abrasi pantai dan menunjang produktivitas hayati. Keberadaan dan ketebalan mangrove alami di sepanjang sungai dan pantai sudah sangat sedikit, lahan mangrove banyak digunakan untuk perkembangan ekonomi terutama kepentingan pariwisata dan perkebunan warga. Berdasarkan kondisi tersebut penelitian stok karbon hanya mendapati satu lokasi mangrove yang berdekatan untuk lokasi pengamatan.

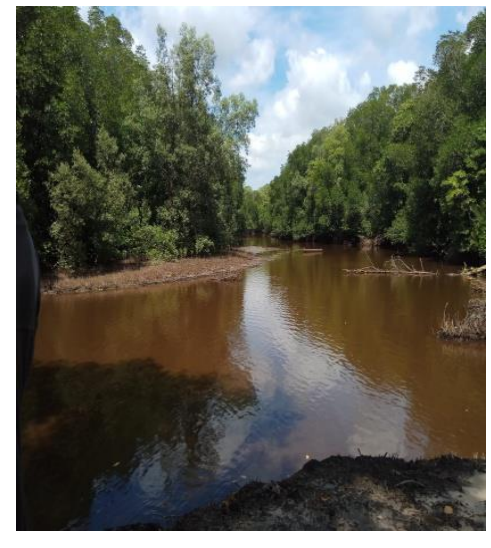

a

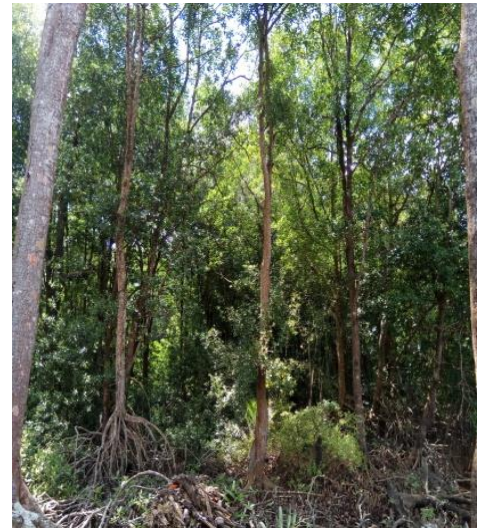

b

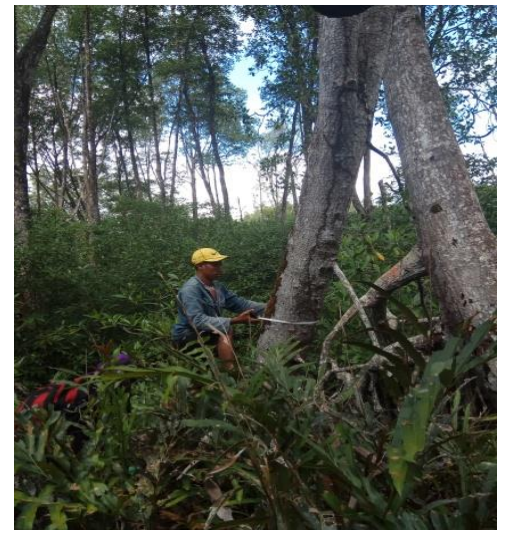

c

Gambar 2. Kondisi pertumbuhan dan kerapatan hutan mangrove (Growth Condition and Density of Mangrove Forest) (a) Pertumbuhan mangrove yang terlihat dari jalur Sungai Etok (b) Kerapatan tumbuhan mangrove tampak tepian Sungai Etok (c) Kerapatan tumbuhan mangrove terlihat dari dalam hutan

Pembukaan lahan mangrove telah membuat beberapa jenis mangrove yang hilang dan merubah jasa ekosistem mengrove sebagai suplai unsur hara dan produksi perternakan. Deforestasi mangrove secara global dan perubahan 
tata guna dapat menyebabkan emisi karbonddioksida $\left(\mathrm{CO}_{2}\right)$ sekitar $10 \%$ atau setara dengan 0,02-0,12 Pg C per tahun (Donato et al. 2011).

\section{Kerapatan Tegakan (Stand Density)}

Berdasarkan hasil pengukuran dan pengamatan secara langsung di lapangan yang dilakukan pada hutan mangrove Sungai Awan Kiri Kabupaten
Ketapang, maka didapatkan lima jenis mangrove dengan jumlah individu berdiameter $\geq 5$ cm-up. Hasil pengukuran secara lengkap disajikan pada Tabel 5.

Kerapatan tegakan :

$\underline{\text { Jumlah individu perjalur }}$ Luas jalur $=\ldots(\mathrm{ind} / \mathrm{ha})$

Tabel 2. Jumlah Pohon yang ditemukan di Lapangan (The Number of Trees Found In the Field)

\begin{tabular}{lcccc}
\hline \multirow{2}{*}{ Jenis pohon } & \multicolumn{2}{c}{ Jumlah individu } & Total Individu & $\begin{array}{c}\text { Kerapatan } \\
\text { (N/ha) }\end{array}$ \\
\cline { 2 - 3 } & Pohon & Diamter & & \\
\hline Bakau (Rhizophora spp.) & 102 & $16,56-76,43$ & & \\
Tumuk/putut (Bruguiera gymnorhiza) & 47 & $20,06-82,80$ & 185 & 308,33 \\
Bakau minyak (Rhizophora apiculata) & 4 & $16,56-41,40$ & & \\
Nyirih (Xylocarpus gerantum) & 2 & $35,99-36,94$ & & \\
Bebutak (Excoacaria agallocha) & 31 & $16,56-45,31$ & & \\
\hline
\end{tabular}

Dari total keseluruhan tegakan yang berjumlah 185 individu yang ditemukan pada ke tiga jalur dengan keseluruhan luas 0,6 ha. Menurut Indriyanto (2005) Kerapatan adalah jumlah individu per unit luas atau per unit volume dengan kata lain, kerapatan merupakan individu organisme per satuan ruang. Menurut standar baku KEPPEM KLH No.21 Tahun 2004, memaparkan bahwa $\geq 1500$ pohon/ha tergolong sangat padat, $\geq 1000$ sampai dengai $<1500$ tergolong padat dan $<1000$ tergolong jarang. Berdasarkan hal tersebut, maka tingkat kerapatan mangrove sungai awan kiri tergolong jarang (308,33 ind/ha). Hal ini dikarenakan hutan mangrove Sungai Awan Kiri Kabupaten Ketapang merupakan kawasan abrasi dan banyak digunakan untuk perkembangan ekonomi terutama kepentingan pariwisata dan kebutuhan warga.
Pada hutan mangrove Sungai Awan Kiri, mangrove yang tumbuh di daerah yang berlumpur dengan adaptasi akar yang berbentuk tunjang, akar nafas dan akar lutut. Salah satu fungsi akar pada jenis mangrove adalah untuk menyerap udara pada kondisi miskin oksigen, semakin sedikit kandungan oksigen maka akan meningkatkan jumlah dan tinggi akar tunjang.

\section{Kandungan Biomassa (Biomass Content)}

Biomassa dan massa karbon merupakan dua unsur penting yang tidak dapat dipisahkan satu sama lain. Biomassa sebagian besar terdiri atas karbon. Penysusun utama dari biomassa adalah senyawa penyusun karbonhidrat yang terdiri dari unsur karbon (C), Hidrogen $(\mathrm{H})$, dan oksigen $(\mathrm{O})$ yang dihasilkan melalui fotosintesis tumbuhan. Hasil perhitungan biomassa 
di atas permukaan tanah dalam ton dari tiga jalur penelitian disajikan pada Tabel 6.

Pengukuran biomassa dilakukan pada jenis mangrove berdiameter $\geq 5 \mathrm{~cm}$ up dengan pengamatan secara menyeluruh menggunakan sebanyak 60 plot pada keseluruhan tiga jalur masing masing jaur terdapat 20 plot, plot dibuat kanan kiri selang seling lebar. Ada 10 plot dikanan dan 10 plot di kiri, lebar jalur 20 meter (dari tepi sungai) dengan panjang 200 meter.

\section{Tabel 3. Kandungan Biomassa (Biomass Content)}

\begin{tabular}{cccc}
\hline Perjalur & $\begin{array}{c}\text { Jumlah pohon } \\
\text { perjalur }\end{array}$ & Biomassa (ton) & $\begin{array}{c}\text { Jumlah kandungan } \\
\text { Biomassa }\end{array}$ \\
\cline { 3 - 4 } & 55 & $\mathbf{0 , 2}$ ha & Ton/ha \\
\hline I & 44 & 79,48 & 397,4 \\
II & 86 & 80,33 & 401,65 \\
III & $\mathbf{1 8 5}$ & 82,35 & 411,75 \\
\hline Total & & $\mathbf{2 4 2 , 1 6}$ & $\mathbf{1 2 1 0 , 8}$ \\
\hline Rata-rata & & $\mathbf{4 0 3 , 6}$ \\
\hline
\end{tabular}

Kandungan biomassa dapat diketahui pada ke tiga jalur mangrove yang menyimpan biomassa sebesar 242,16 ton dan jumlah kandungan biomassa sebesar 1210,8 ton/ha dengan rata rata kandungan biomassa sebesar 403,6 ton/ha. Pada ke tiga jalur jenis mangrove didominasi oleh Rhizophora spp dengan jenis tanah yang berlumpur dengan adaptasi akar yang berbentuk tunjang sehingga banyak ditumbuhi jenis mangrove Rhizophora spp Salah satu fungsi akar tunjang pada jenis mangrove ini adalah menyerap udara pada konsdisi miskin oksigen, semakin sedikit oksigen maka akan meningkatkan jumlah dan tinggi akar, Menurut hasil penelitian yang dilakukan oleh Heryanto dan Subandono, (2012) dan Rachmawati et al. (2014) nilai biomassa jenis Rhizophora spp lebih besar dibandingkan jenis mangrove yang lain.

Selisih perbedaan kandungan biomassa pada ke tiga jalur jenis mangrove tersebut secara umum kompisis vegetasi di hutan mangrove Sungai Awan Kiri. Jalur 1 tergolong rendah memiliki biomassa sebesar 397,4 ton/ha dikarenakan ada bebarapa plot yang tidak ditemui jenis mangrove berdiameter $\geq 5 \mathrm{~cm}$ masih banyak tingkat semai serta ada pembuatan jalur nelayan sehingga ada beberapa jenis mangrove yang hilang. Jalur 2 kandungan biomassa tergolong sedang sebesar 401,65 ton/ha dikarenakan masih ada beberapa plot yang tidak ditemui untuk ukuran diameter $\geq 5 \mathrm{~cm}$ tingkat pertumbuhan rapat untuk semai. Jalur 3 tergolong tinggi kandungan biomassa 411,75 ton/ha dikarenakan dekat dengan muara sungai yang berdekatan dengan pantai, ada 2 jenis didominasi dengan jenis Rhizophora spp dan Excoecaria agallocha tingkat pertumbuhan rapat masih ada dijumpai tingkat semai. 


\section{Kandungan Karbon Tersimpan (Stored Carbon Content)}

Salah satu hutan penghasil karbon yaitu, hutan mangrove sebagai bagian dari hutan primer yang dianggap sebagai kandungan karbon yang penting karena diperkirakan memiliki potensi cadangan karbon tertinggi di kawasan tropis. Dari gambaran hutan mangrove di Kalimantan, salah satunya hutan mangrove Sungai Awan Kiri Kabupaten Ketapang, semakin hari semakin berkurang akibat Area Penggunaan Lain
(APL) sehingga dengan berkurang nya kerapatan mangrove, maka diperkirakan stok karbon yang tersimpan menjadi berkurang.

Perhitungan nilai karbon yang tersimpan dilakukan menurut (SNI 7724:2011) yaitu, kandungan karbon dari bomassa dilakukan dengan 0,47 atau menggunakan nilai karbon yang diperoleh dari hasil pengukuran di laboratorium, sehingga diperoleh hasil dilihat pada Tabel berikut.

Tabel 4. Kandungan Karbon Tersimpan (Stored Carbon Content)

\begin{tabular}{cccc} 
& & \multicolumn{2}{c}{ Jumlah karbon tersimpan (ton C) } \\
\cline { 3 - 4 } Perjalur & Jumlah pohon dalam jalur & Per 0,2 ha & Perhektar \\
\hline I & 55 & 37,35 & 186,77 \\
II & 44 & 37,75 & 188,77 \\
III & 86 & 47,70 & 193,52 \\
\hline Total & $\mathbf{1 8 5}$ & $\mathbf{1 1 3 , 8}$ & $\mathbf{5 6 9 , 0 6}$ \\
\hline Rata rata & & $\mathbf{3 7 , 9 3}$ & $\mathbf{1 8 9 , 6 8}$
\end{tabular}

Kandungan karbon tersimpan pada hutan mangrove Sungai Awan Kiri sebesar 569,06 ton C/ha sehingga didapatkan total rata rata sebesar 186,68 $\mathrm{C} / \mathrm{ha}$. Intensitas karbon terbanyak pada jalur 3 sedangkan yang terkecil di jalur 1. Jalur 3 terdapat karbon terbanyak yaitu sebesar 193,52 ton C/ha. Hal ini diakibatkan jalur tersebut mempunyai jumlah pohon yang banyak serta diameter yang besar dimana jumlah pohon dan besarnya diameter pohon di pengaruhi besarnyan karbon. Sedangkan karbon terkecil terdapat pada jalur 1 yaitu sebesar 186,77 ton C/ha. Hal ini diakibatkan karenakan masih banyak pertumbuhan pohon yang tergolong kecil dan berkurangnya mangrove akibat pembukaan jalan bagi nelayan.

Dari hasil pengamatan yang telah dilakukan penulis dapat dibandingkan dengan penelitian yang telah dilakukan oleh Windarni et al. (2018) dilihat pada grafik berikut : 


\section{Perbandingan Karbon Tersimpan (Ton C/ha)}

189,68

197,36
Windarni

kusmawati

Gambar 3. Grafik perbandingan hasil yang didapat oleh penulis dan Windarni et al. (2018)

(Comparison Chart of the Results Obtained by the Author and Windarni et.al.2018)

Berdasarkan dari grafik dapat dilihat bahwa perbandingan menurut Windarni et al. (2018) menunjukkan kandungan karbon tersimpan yaitu sebesar 197,36 ton $\mathrm{C} /$ ha. Hasil yang didapat oleh penulis menunjukkan kandungan karbon tersimpan yaitu sebesar 186,69 ton C/ha artinya sebanding dengan hasil yang didapat oleh Windarni et al.(2018).

Berdasarkan nilai biomassa dan karbon di atas permukaan tanah Kalimantan Barat, didapatkan data nilai AGB untuk hutan mangrove sekunder biomassa sebesar 113,79 ton/ha dan karbon tersimpan sebesar 53,48 ton $\mathrm{C} / \mathrm{ha}$ sedangkan untuk data AGB hutan mangrove primer dalam perhitungan FREEL Kalimantan Barat mengacu pada data $\mathrm{ABG}$ hutan mangrove primer nasional. Nilai biomassa dan karbon di atas permukaan tanah di Indonesia (Kalimantan), didapatkan data nilai AGB pada hutan mangrove primer sebesar 263,9 ton/ha dan karbon tersimpan sebesar 94,799 ton C/ha (Hardiansyah et.al. 2014)

Berdasarkan data tersebut, dapat dibandingkan dengan hasil penulis nilai biomassa dan karbon tersimpan pada hutan mangrove Sungai Awan Kiri Kabupaten Ketapang kandungan biomassa sebesar 403,6 ton/ha dan karbon tersimpan sebesar 189,68 ton $\mathrm{C} /$ ha sehingga hasil yang didapat oleh penulis lebih besar. Hal ini hasil yang didapat penulis termasuk pada hutan mangrove mangrove primer nilai biomassa dan karbon di atas permukaan tanah Kalimantan Barat.

Simpanan karbon menggambarkan besar suatu pohon dalam menyimpan karbon. Besar kecilnya simpan karbon suatu vegetasi tergantung pada jumlah biomassa yang terkandung pada pohon, kesuburan tanah dan daya serap vegetasi tersebut (Ati et al.2014). Hasil yang ditemui besarnya lingkaran pohon mangrove Sungai Awan Kiri disajikan pada gambar 6 sebagai berikut: 

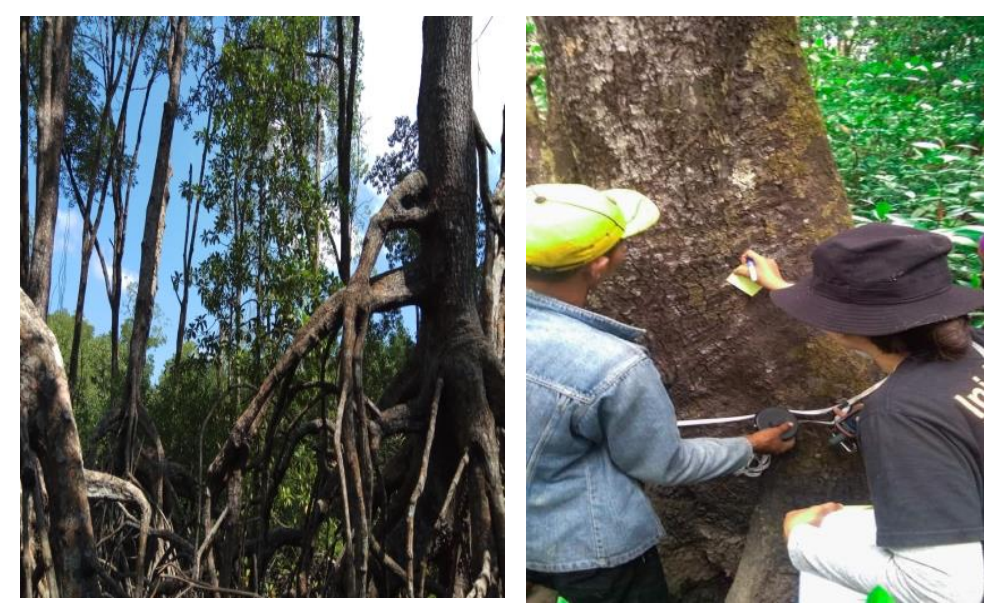

b

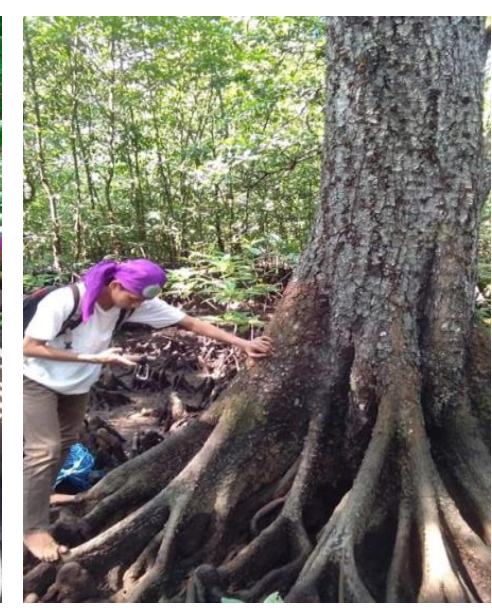

$\mathrm{c}$

Gambar 4. Besarnya pertumbuhan lingkaran pohon pada hutan mangrove (The Amount of Tree Ring Growth In the Mangrove Forest). (a) Besarnya diameter akar tunjang pada jenis Bakau (Rhizophora spp). (b) Ukuran diameter pohon pada jenis Tumuk/putut (Bruguiera gymnorhiza). (c) Salah satu jenis mangrove Tumuk/putut (Bruguiera gymnorhiza).

Menurut Heriyanto dan Subandono (2012) kandungan karbon pada tanaman menggambarkan berapa besar tanaman tersebut dapat mengikat $\mathrm{CO}_{2}$ dari udara. Tumbuhan menyerap $\mathrm{CO}_{2}$ dari udara kemudian mengkonversinya menjadi bahan organik melalui proses fotosintesis yang digunakan untuk pertumbuhan. Tingginya kandungan karbon organik sedimen di suatu vegetasi disebabkan karena substrat menerima sumbangan karbon dalam bentuk daun, ranting, buah dan bunga yang mati (serasah) (Brown, 1996).

\section{Kesimpulan}

Berdasarkan hasil penelitian yang telah dilakukan dapat disimpulkan bahwa kandungan karbon tersimpan (stok karbon) pada hutan mangrove Sungai Awan Kiri Kabupaten Ketapang sebesar 569,06 ton C/ha. Sementara itu, kandungan biomassanya sebesar 1210,8 ton/ha. Rata-rata jumlah kandungan biomassa yaitu sebesar 403,6 ton/ha sedangkan rata-rata jumlah karbon tersimpan yaitu sebesar 189,68 ton C/ha. Hutan mangrove Sungai Awan Kiri Kabupaten Ketapang termasuk hutan mangrove primer ke dalam nilai biomassa dan karbon di atas permukaan tanah Kalimantan Barat.

\section{Saran}

1. Hutan Mangrove Sungai Awan Kiri Kabupaten Ketapang, dapat memberikan jasa lingkungan berupa stok karbon $\left(\mathrm{CO}_{2}\right)$. Nilai karbon yang terkandung pada vegetasi mangrove merupakan potensi dari mangrove dalam menyimpan karbon (stok karbon) dalam bentuk biomassa. Bagi kegiatan pengelolaan hutan, diharapkan dapat menjadi dasar bagi kegiatan pendugaan stok karbon pada hutan mangrove tersebut yang akhirnya juga dapat berguna sebagai 
bahan pertimbangan keputusan pemanfaatan hasil hutan mangrove.

2. Perlu penelitian lebih lanjut agar mendapatkan hasil yang lebih akurat, melakukan penelitian seperti (daun,serasah, akar) pada hutan mangrove.

\section{DAFTAR PUSTAKA}

Ati RNA, Rustam A, Kepel TL, Sudirman N, Astrid M, Daulat A, Mangindaan P, Salim, HL, Hutahaean AA. 2014. Stok Karbon dan Struktur Komunitas Mangrove Sebagai Blue Carbon di Tanjung Lesung Banten. Jurnal Segara. Vol. 10 (2) : 98-171.

Bakar S. 2012. Peran Pemerintah dalam Pengelolaan Mangrove di Indonesia. Presentasi International Seminar On Mangrove. Conservation and Community Empawerment. Satgas REDD+. Jakarta.

Brown Sandra. 1997. Estimating Biomass and Biomass Change of Tropical Forest : a Primer. Rome; FAO.

Chanan M. 2012. Pendugaan Cadangan Karbon (C) Tesimpan di Atas Permukaan Tanah Pada Vegetasi Hutan Tanaman Jati ( Tectona Grandis Linn. F). Jurnal Gamma. Vol. 7 (2) : 61-73.

Donato D, Kauffman JB, Murdiyarso D, Kurnianto S, Stidham M, Kanninen M. 2012. Mangrove adalah Salah Satu Hutan Terkaya Karbon di Kawasan Tropis (No.CIFOR Infobrief no. 12, p.12p). Center for International Forestry Research (CIFOR), Bogor, Indonesia.

FAO. 2007. The world's Mangroves 1980-2005. Forest Resources Assessment Working Paper No.153.
Rome: Food and Argiculture Organization of The United Nations.

Hairiah K, Rahayu S.2007. Pengukuran Karboon Tersimpan di Berbagai Macam Penggunaan Lahan. http//www.worlandgroforestycentre .org/sea. Diakses Tanggal 06 November 2019.

Hardiansyah G, Yani A, Jamani R, Fahrizal, Erianto, Yuslinda, Jeno M, Ngo LY, Manuputty BDR, Darmawel,Yenny, Sari SE, Rosadi, Haryono Z, Iskandar, Idham M, Iiyas, Zailani, Sholatiana, Irvanto FA. 2014. Strategi dan Rencana Aksi Provinsi.

Heriyanto NM, Subiandono E. 2012. Komposisi dan Struktur Tegakan, Biomasa, dan Potensi Kandungan Karbon Hutan Mangrove di Taman Nasional Alas Purwo. Jurnal Penelitian Hutan dan Konservasi Alam Vol. 9 (1) : 023 - 032.

Komiyama A, Poungparn S, Kato S. 2005. Common Allometric Equations for Estimating The Tree Weight of Mangroves. Vol 21, Ed. 2, McGraw Hill Inc, New York.

Manuri S, Putra CAS. dan Saputra AD. 2011. Teknik Pendugaan Cadangan Karbon Hutan. Merang REDD Pilot Project, German International Cooperation-GIZ Palembang. http//www.merong-redd.org.

Tanggal Akses 10 November 2019.

Peraturan kepala Badan Informasi Geospasial No. 3 Tahun 2014. Pengumpulan dan Pengelohan Data Geospasial Mangrove. Cibinong, Bogor.

Rachmawati D, Setyobudiandi I, Hilmi E. (2014). Potensi Estimasi Karbon Tersimpan pada Vegetasi Mangrove 
di Wilayah Pesisir Muara Gembong Kabupaten Bekasi. Jurnal OmniAkuatika Vol.10 (2) : 85-91.

Senoaji G, Hidayat MF. 2016. Peranan Ekosistem Mangrove di Pesisir Kota Bengkulu Dalam Mitigasi Pemanasan Global Melalui Penyimpanan Karbon. Jurnal Manusia dan Lingkungan. Vol 23 (3) (2016).

Sulistiyowati H. 2009. Biodiversitas Mangrove di Cagar Alam Pulau Sempu. Jurnal Sainstek Vol. 8 (1): 59-61.

Suryandari P, Astiani D, Dewantara I. 2019. Pendugaan Karbon Tersimpan pada Tegakan di Kawasan Arboretum Sylva
Universitas Tanjungpura. Jurnal Hutan Lestari Vol. 7 (1): 114-122.

Spalding M, Kainuma M, Collins L. 2010. World atlas of Mangrove. United Kingdom: Earthscan Publiction.

Tiku M. 2007. Hutan Bakau, Ekosistem yang Perlu di Lestarikan. http//dephut/kalbaroutline/TNGP/2005. Tanggal Akes 04 November 2019.

Windarni C, Setiawan A, Rusita. 2018. Etmisi Karbon Tersimpan pada Hutan Mangrove di Desa Mangasari Kecamatan Labuhan Maringgai Kabupaten Lampung Timur. Jurnal Sylva Lestari Vol. 5 (1): 66-74. 